\title{
Moratorium est finie
}

\section{Wilfrido D. Nolledo}

One existential night Vorgis IV and Bartolome $\mathrm{V}$ sat dreaming poles apart, in terra firma of varying climate and automation. Now $\mathrm{V}$ was born paraplegic, as was B; and both were guilty of parricide in adolescence. Neither knew the other by sight but had to this date corresponded prolifically-oh, such electric love letters, punctuated by all manner of dash and diminuendo. This infatuation was all the more chaotic since it was stagebound, blessed with neither touch nor token, yet producing a pas des deux nonetheless. Their favorite charades: Deux ex machina. Having conceived a bestiary, they also concocted a real weirdo: Man, a composite-facsimile drawn from oral legends. Their love letters then were hypothalamusical-partial to artifacts corroborating the historicity of Romeo and Juliet, even extending to a definitive chronicling of Adam and Eve. Such thesis-baiting and its resultant rhetoric ignited V \& B, who were of the eidetic syndrome. And quite lovingly,-always by long distance-they would litigate cases of biblical/ historical amour. Ergo: wasn't Anne Bolynn a mite too incontinent for the brutish Henry VIII? Had Samson been ahead of his time and refused to be clipped, Delilah wouldn't have that maxi-rep today. Like that. V's and B's integrated memories were inexhaustible; they could ad lib eternity. Regardless of how tuned-in they were, V \& B were doomed to an inertial worship. Like mummies, they were encrypted, unrequited. Vibration was their umbilical; and in this they were pathological linguists. Their ardor hinged on voltage, frequency. Should they ever come together, their copulation would have to be nothing short of cannibalism. Orgasm could be traumatic to both. The realization that they were physically anathematic dimmed this otherwise radiant twosome. To compensate, they resorted to telepathy, malevolently and multilingually.

Therefore...

B's deviation in French postcards was subtitled by $\mathrm{V}$ just as graphically in Chinese expletives. Sometimes, when they were really zonked, B's masturbative Morse was decoded by V in scatological Swahili. Tranquilizers, titillations. Was $\mathrm{V}$ in a Filipino bag? Ping! B countered with isometric graffitti which degenerated into pidgin-idgin, ad nauseum. From yen to Zen. Such was their sexual surrogate. Playing it by ear eventually palled. As innovative as they had been, they agreed that their libido could be sublimated by a more rewarding gambit.

-Eureka! 
Their new brainchild was a communal dream, to be hatched on empirical motivations, to be reordered according to a leitmotif.

-But, wired V,-the traditionalist of the pair-that'd only be seduction without representation. Let's-and getting quaintly idiomatic here-make it for real and peak the dream into a lovers' quarrel! To which $B$, nursing erogenous vertebrae, beamed:-Bravo and kisses to you! What an authentic gas! We'll fantasize and impede each other's ethnocentrism.

-Hey, are you on junk or something?

-We're going to have a ball, comrade, screeched B,-since we can't . . .

-Dirty old man, parried V.

-But how should we presume?

-Christ, improvise, rhapsodize!

-Should be a monumental expo, no?

-Funky, yes.

-Archaic!

-Vendetta! Vendetta! My \#\%\$\&! for a vendetta!

-Anything wrong, love?

-Just a systolic-xxxxx-murmur. Nothing I can't harness.

-Venting, huh.

-Rules of the game?

-Contrapuntals. You fabricate, I dislocate.

-Premise to putrefaction?

-Call it, Laser-lips.

-Please, no technological advances-dah-ling!

-How inchoate!

-Shape up now. That old ABM.

-You asked for it, Esperanza.

-Look who's calling who names-Desdemona.

-Would you accept Rasputin?

-Spassivo for nothin, Ivan.

-Don't get up tight.

-On your telefactors!

-Dream ahead.

-A-okay, all systems are go!

Into quasars-primero for V, seconded by $\mathrm{B}$. Tingling with sensors, V adumbrated into reverse, into reverie. Clunck + clunck. CORRECTION: THERE IS NO EQUIVALENT FOR THAT IN YOUR UNIT STOP SINCE REV-EEEKKK!RIE IS CLASSIFIED EM-O- . . . So V hurriedly switched gears, U-turned and was soon smoothly functional. Dreaming, to be sure, was no electrophoresis even for V's madcap ingenuity, it requiring that most decadent of feedbacks: a psyche. However, given the plutonium thrust of a highly structural sorcery, V could not but approximate the dream state. En route, a few clinkers, consecutive errative maneuvers yielding a montage of schematic data which $\mathrm{V}$ instantly recognized as substandard modes of operation. Getting the Iliad out of hock, for instance, represented not causation but coercion. To explain: V's anomie was wont to Hell- 
enize, which was, bleeped B, R-E-G-R-E-S-S-I-O-N deserving a reprimand, if not a demerit. Such cautionary measures did not deter V. V essayed Chopin, but that atrocious piano playing was discordant to the nerves; so skipped over to the sitar. Pseudo-cultural, foreign exchange: negative quotient. The flicks? That droll cinéma verité? Unfortunately, $\mathrm{V}$ could not recall ever endorsing one-except possibly that Satyricon something which was nearer to home. From such fanfaronades, it was dubious that a valid V dream could emanate. Somehow V had to transcend mass media. Certainly, re-coding Don Quixote was to concede that Cervantes was an entity? Veep! Veep! Hurry up, reminded B. Ignoring the hot-line, V was determined to collate, to synthesize. Pero que? Why, current events and their dramatis personae! In ambivalences lay the Soma, probably semantical, but dreamers couldn't be choosers. For openers, V opted for three genre-myths: a) Iago for jealousy; b) Hitler for ideology; and c) the Kennedy Era for charisma. Thus did $\mathrm{V}$ communicate his dream to B-initially with quantum disdain; a cameo bursting for crypto-psychedelia. Pop-manque verbalized thru dialectic-conveyors. V's prologue...

1

Quasimodo Bolivar-for such was his title-profiled at the lectern, oblivious of those jugular mikes; miming in so many nuancey tics the heroic fact that his speech before the collegium was extemporaneous and that, tic-tic, the medium was his mind. Nothing if not arrogant, of course, as he choreographed the anatomy of Diplomatic Stance. And for those who are tube-oriented, mark that: a) The Stanislavskian crouch is out; b) Ditto Black Power bombast; and c) Go easy on "sincerity." Moral: not only must you keep your cool; play it glacial. Remember it's The Age. Plus a $u$ in between.

\section{SANS WARMUPS AND WITHOUT AS MUCH AS A BY-YOUR-LEAVE, B JUXTAPOSED THIS EXQUISITELY WROUGHT CADENZA WITH WAG- NERIAN ORATORIOS ...}

\section{2}

Meanwhile (interpolated B) the Chicago 4000 had long hijacked Module Jude; had colonized Jupiter, introduced pollution (antediluvian pot, shaggy HAIRstyles, ersatzy beards, etc.), and had finally been annihilated-according to their last monitored SOS-by a symbiotic tribe of Jupiterians known as Jup-Urs. In Taurus-Uganda, they were celebrating another Southern Centennial, attended by Candy \& Condomites-yeh, what revelry and rhubarb! Hot on the perimeter of Gemini-Apartheid XIXX was the Chilean Abort-in whose primates were fresh out of geodesic-domes, Zambian bordellos, Malibu Beach and several with-it nunneries. Also in the late news (Crotch-44) was the latest reprisal of a predatory band called Pynchon 77 (as of this epoch, still hung up on V and its sewer crocs) who, in gleeful protest $v$. interstellar commuting, was tunneling into the Basaltic crust via Phoenix, Copernicus. Motley but menacing, the $77^{\prime}$ ers sported spade-andpitchfork-embroidered armbands (Earth Daze, see), subsisting on stalagmite cacti in their weekend excavations. For 17 weeks local authorities covered the cabal's dug-out holes with mayonnaise and spittle; the former, courtesy of an Eagle supermart stockpile. Yet the vigilantes' damnedest was for naught since the dis- 
senters merely feasted on the sticky white stuff and nonchalantly shoveled away. With an uuurrggghhh! here and an oooeeekkk! there, the soil conservationists, panting on their badges, redressed their oil fields. But brrrsss! and also whssssss! the spade cadre opened up the bleeding sediment again, until that embattled terrain took on the cratered look of those recently annexed comets above and beyond the cull of aerodynamics. Tourists munching on cosmonaut rations were trucked in by the droves or choppered down with what was all the rage in the Eratosthenes Trans-Vaal coal depositories-Dante Survival Kits. This Mardi Gras atmosphere did not abet Phoenixians' Beautification Plans any, but it was bread, sister, along the helium coasts of the ozone shield. One fruity evening, this Deputy Marshal did tank up for Armageddon. Boozed silly and swearing decibel-deep within moonshot of his astral-ancestral grandpaws and grandmaws, he stumbled into the arena, joshed by all them xenon dudes cordoned between Phobos and Deimos. Well, staggering and swigging among all those ever escalating pockets of methane void (a Cuban drop-out was seen fishing at one of them), he confronted the horniest pit of the lot: how cheeky, how circular, the width and depth of the 77'ers' serendipity-decked on four sides (the D.M. was a myopic square) with neon weeds, argon grass; moist and pubicky, darkening into familiar female thatch by every nocturnal hour. Ah'll be d-d-dang! muttered the cosmos ranger, immediately stripping en toto, pulling out his four-dolphins-so-far krypton of virility: AND-STUCK-IT-INTO-THAT-MAMMOTH-HOLE. Down down down he went, plummeting into that aboriginal whore, the Mare Imbrium, which was truly spatial and just plain out of sight. However, that incorporeal stopgap was only an interim. More was yet to come; phylogeny, temperature leakage and polarization breakthroughs were the big noises . . .

PIQUED AND CONSIDERABLY RATTLED, V SNATCHED UP THE TANGLED FLOTSAM OF DREAM DETAILMENT. V'S ARTISTRY, COUPLED WITH GENTILITY, REVISED B'S THUNDER INTO

3

a hush upon the audience: as Quasimodo Bolivar fondled syntax into eloquence. Who could resist this epitome of the bon vivant made relevant with a generous helping of noodles? His communique was crisp but consummate, never too cerebral nor too condescending. Just right, say, like graphite almonds in an alien's tender. Quasimodo B. was programmed for perfection. His theme: Computer Conservation. Defending it, embellishing on same with mesmeric passion. Design, he continued (sonorous as hell), is all. Design that is, he enunciated, not of the commercial variety, but in the Cassandran sense. Think totems, exhorted he, his lean frame defining monoliths and Mariner probes. We are, he exclaimed, losing rapport with The Machine. All that incendiary talk about The-Good-Old-Days-WhenEverybody-Still-Had-To-Push-Buttons incurred the wrathful residue of NothingEver-Works-Anymore. Tinker, not think! rallied Quasimodo Bolivar, whose forebears were carillon fetishists. He itemized the evils of negligence (always oil your thing), the inequities of overuse (watch that exposure), the tyranny of delay (keep the options, baby!) The colosseum was teeming and athunking; oboe-extract was piped in through castanet-shaped amps; three tiers removed, a kosher kinetica was doing brisk business with minted octane. Metal buntings whirred in 
the precipitation-free monsoon; and traffic was sedate, what with those vaporized commodes. What these vehicles were were "transcience chambers" wherein riders inhaled for ignition and exhaled for debarkation. "Fart-outs," as a pundit aptly described them. Progress does what God postponed. Taxi! Whereupon a metered cab, its hack none other than that irrepressible B, pulled up on the curb to reroute V's allegory-therefore moralizing-into Machiavellian alleys littered with ticker-tape citations. No indentions, just locomotion-B's imprimatur on style.

4

Thence to Waikiki where the surfing had stopped. And what would beachniks do for breakers? No water; just a plenitude of magma. Japan's Mount Fuji was renovated into a Disney-type freeway, banzai! Uhuru! Taxidermists shrank the Congo into prophylactics. The forum finished, the canapes consumed, Quasimodo Bolivar was shortly Superjetting to the stratospheric navel, accompanied by echelon observers for the Pan-Pacific Theosophy Confederation. Made up of Molotov Militants, Micro-mini Specialists, Mushroom Bartenders, Bacteriological Bankers, Radium Philatelists, Neuron Numismatists, Grand Keepers of the Atom, Uranium Utilitarians, and so forth and so on down the hybrid production line.

WHO'S ON FIRST? INTRUDED V, FORTHWITH GIVING B'S TELL-TALE TOE A HOTFOOT WITH

\section{5}

in time, observed a Rosicrucian, chemists will patent in lieu of spirits of ammonia, the soul itself; cytogenetics will determine not only its gender but also its jurisdiction-to be purified by Eastern arahats! This outburst was blissfully ignored by his peers on the grounds that it was predicated on, ugh, romanticism. Nobody wanted a renaissance of Black Voodoo which had polluted a generation with that terminal blueism presumptuously referred to as "Soul Music." Doubtless, the Rosicrucian species had to be exterminated but quick-embarrassing! Moreover, this doomsdayer was hallucinating. Tense, per se, in any context, was no longer pertinent. Ultra-mod Einsteinians had deftly discombobulated that theory with the, uh, old hairpin-in-the-hatbox trick for, uh, all time. Time (Serbo-Croatian mathematicians were founding a new terminology) didn't exist now; "now" as a modifier was just as extinct, for the "moment" was the "future" and what used to be "tomorrow" was in actuality the "past" that calendarists were attempting to disenfranchise. Something to do with "recycling."

DETENTE WAS THE NAME OF THE GAME AND B WAS NO SLOUCH. INTERCEPTING A LOOSE BALL BEARING, B UNLEASHED A GAMMABIT ...

6

On a scramble-alert, Bolivar \& Party alit from their Turbo-Persian Tabriz to mediate in the United States of Andromeda. Ethnically, neo-Americans were anthromorphous projectiles traceable to the planet Earth before its decimation. By a divine right of nuclear kings, cadavers of the elite were sealed in hibernacula troikas; each sarcophagus was then shot into the asteroid womb, like cosmic bacteria infiltrated into an extraterrestrial bloodstream. Classified as "Viking Cryogens," the immigrants were reactivated by transistor synchrotrons. A scant century 
since their exodus, they found themselves dislocated in a savanna south of the Nebula A. Soon, they were conscripted as galactic slaves by a warrior class of Andromedans who overseered magnesium plantations. Cryogens were herded on spaceships, auctioned off lunar blocks, and were generally discriminated against owing to their "earthly complexion." Their rebellion was punished with dehydrations; some genocidal southerners even considered mass-lobotomy. In the north, liberals petitioned for racial equality. There were debates, referendums; consequently, a civil war. The North won; the South was obliterated. Later: Abolition, Reconstruction, Recession, Prohibition, Depression, New Deal. Although Assimilation became a law, Cryogens never quite shook off the stigma of a "bastard minority." But mechanarchy was the great equalizer. Pigmentation and territoriality seemed infantile on the threshold of "orbital conjunction." Urbanization allied regional planners, amalgamated agrarianists, landscape colorists, flora-and-fauna comptrollers, commune commandoes, zoological custodians and ecological ministers. All of them brothers under the smog, you understand. Some pastoral reactionaries notwithstanding, the U.S.A. was prospering as per computations; her manifold industries steadily crunching on the upswing without evoking the crassness of a boom.

Bolivar \& Checkers couldn't have been happier. Way to gol Neptune Europa was coy, though. France was re-antiquating as a tribute to Gaullism. True, no demonstrations (woulda been too gross); but some programmers-due to an autosclerotic malfunction-were actually agitating for screwy reforms. Quasimodo Bolivar made a mental memo: All right, which button was it? Onto Berlin where it wasn't a ring-a-ding-ding either. Some chancellor, it seemed, had the gall to veto the prerogative of Operator-what's-its-name?, which was treason. Memo: Jettison culprit to one of those underdeveloped galaxies. After that Final Confrontation, the U.S.S.R. was enjoying a period of manic subtlety. As the CIA had successfully quashed its campus radicalism, the KGB had purged itself of all that proletarian jazz. Ideological colorations had long ceased; for Red slogans, Think Pink had been substituted. There were still straggling vodka-swilling commissars, altho they were less cant than camp. The English had depressurized parliament; their vestigial royalty being those scented waxworks in scattered organ banks. A stubborn Liverpool had amplified static to an aesthetic by laboriously exporting canned hysteria-mutations of imaginary beetles. Fortunately too Sweden had dumped her antiquarian fancies about sex and suicide. No more passion and porno. Just ice floes and an ethnic splurge: the Penultimate Cool. Much of Italy was subservient yet quirky, ripe for re-evaluation. Many Rotarians procrastinated in ducal palaces; others were suspiciously harking back to demimonde days-Quasimodo Bolivar noticed some crappy Moulin Rouge posters; and also a mafioso faction with pretensions of omerta. While the universal technocracy tolerated ESP, this was going over the hill. Memo: A putsch? Spain was still smitten with the corrida. Bull! rasped Quasimodo Bolivar, jerking off on his consoles. What was maddening about these Castilians was their sophomoric duplicity. Por ejemplo: their aficion had no bulls, no bullfighters, not even a bullring. What they had-sneaky!-were balletomanes spiralling between gold-braided capotes, exhuding if not assuming the ridiculous postures of that pagan art. Memo: Shoot that trumpet player! Else- 
where, other signatories logged in this western itinerary were under probation. The Middle East on Uranus? Touch and go. Mostly touchy. Quasimodo Bolivar's transmitters hummed with annotations and parenthetical amendments. The ArabIsraeli merger was ludicrous in its cupidity. Hmm. Transplants weren't what they used to be. Memo: Watch that shit, Buster! Pluto's Southeast Asia proved to be the jigsaw. In terms of population explosion, that area was cathartic. Firstly, no explosion; secondly, no population. That Deluxe Detergent had literally siphoned SEA from filth to foetus. Like the Namu Complex during those primitive A-Bomb tests, SEA was predominantly Kalahari Desert in mood and texture. Laos, Vietnam, Thailand, Cambodia and the Philippines shared a vacuity made incomprehensible by the fact that in each trajectory, there was all this polymorphous rice in titanic growth, with no one to harvest, much less eat it. Ah, surmised Quasimodo Bolivar, somebody got a bit overzealous somewhere. Memo: Enterprise but not overdose. In spite of these irritants, there was no reason why the trip couldn't be trendy. Quasimodo Bolivar tossed down a malted Daiquiri and dozed off in his cabin, serenaded by labial samisens (which came in pastel pills this Spring) and cooed over by wind-up stewardesses (pick your pedigree) ...

THE DREAM WAS HEADED FOR TURBULENCE AND NIMBUS REEFS, SO V FUMED AND CRANKED AND JAMMED ITS THEMATIC DICHOTOMIES UNTIL, ALL PURPLY AND INFLAMMABLE, THIS EPICAL ERUPTION WAS MAINLINING FOR A DEMOGRAPHIC RE-ENTRY . . .

7

For a lark, Quasimodo Bolivar had decamped, foisting off his cronies on some Alpha Centaurian conventioneers, then himself chartering a UFO scab somewhere near the Aleutian Highway, and setting his control panel for Fra Mauro. In one of his priority transmissions, he'd been informed that a dowager centenarian was holding court there, amidst archetypal serfs who danced ceremony around her with dated dictaphones and xerox oldies. Another fanatic, thought Quasimodo Bolivar, revving on while summing up the dowager's dossier. Not infrequently, the United Notions received bulletins on indigenous goof-offs who, by and large, espoused Mid-Martian sentiments calculated to undermine the status quo. Ay, an umpire's task was never done. Zoom! There he was, smack-center in moribundity. Ping! At her doorstep, pronto. Swissssh! Right in her posh pad, sipping old-fashioneds. OUTJOCKEYING V ON THE SWITCHBOARD, B OVERHAULED SEQUENTIAL CHRONOLOGY WITH THAT OLD SLEIGHT-OF-CONJUGATION TRICK . . .

\section{8}

There is an aura of fiesta, a recurring salvo of hand-clapping mingled with caracole chanting as the dowager (inescapably bovine) makes her appearance. She is wearing a formal sequinned gown, a pearl choker (gasp!), and, good grief, elbowlength satin gloves. A silvery orchid strand sets up her long tresses-for a phony Grecian effect. And when she waddles forward while Quasimodo Bolivar is having a hard-on, it's as though \#\%\$\&! . . V SNAGGED THE RELAY AND . . . Pallas Athena herself had descended from Mount Olympus to consort with an earthling. A bow, a courtesy; peripheral amenities ... 
Says she: "In Atlantis, the actual deliberations took nine months-the length of an anthropoidal pregnancy. A thousand demonstrators were killed in the riots; 99 others wounded. They also imported the Calypso, and there was acid-marimba, perpetual limbo, dancing on the countdown. When the thousand martyrs were buried, every single petal in Atlantis was bought and each one became a flag . . . for days it rained roses, gardenias, hyacinths, sunflowers. It was said that in Atlantis, 900 mothers immolated themselves ... the rest grieved and fasted while the deliberations went on."

Forensics to heckle Quasimodo Bolivar. Incredible as it seems, that sardonic leer has vanished from the Ambassador Extraordinaire's mug. After that rambling fugue, she reverts to her mission of harassment. He gives her a sharp glance, then fishes out a cheroot; fumbles for a light.

Says she: "I was at the opera one night, decades ago. It had been announced that underground musicians would perform the 'classics.' But at the crucial minute, the Philharmonic Society reneged. Predictably, we were treated to more of the same-a refab repertoire. Atonal, toneless, musicless. Oh, I couldn't blame the conductor. Being expendable, he had to conform. Yet I heard that when he was alone, he repaired to his basement and took out banned $33 \mathrm{rpms}$ of Bach and Brahms .... I read how in Andromedan suburbia each above-average family had this 'impulse' jukebox installed. Played the Top Ten in non-records; or, as trade parlance put it, the Radar Scales. No notes, no melody, no harmony. The blind then had this Precocious Braille ... spelled the alphabet electrically at the slightest pressure of the fingertips. The Book-of-the-Month Club sponsored their Best-Friction-of-the-Year Award . . . prose printed in cerebro-types; no text, just electrodes affixed to the verbs. Movies were sheer leviathans. The last musical I saw had two robot tenors and a baritone asbestos lung. Hero was a disembodied brain graft ... . died after taking an aspirin-acute Excedrin headache, I guess. Story was adapted from Gogol's Dead Souls by a cipher scenarist. At the Academy presentations, Mr. Cipher, visibly moved, with keotane streaming down his iron cheeks and the tiger in his tank pumping up euphemisms, thanked all the nuts and bolts in his employ. Have you read the Nobel Prize novel? Title: Inside Aurora Borealis. Written by an electrician, no less. The first Fallout Olympics on Mars was called on account of lightness. And what about the Venus Grand Prix ...?"

Before Quasimodo Bolivar can respond, the dowager's gnomish butler materializes from nowhere, and croaks: "Did you ring, Madam?" To which she nods imperially: "Gasper, escort Señor Bolivar to the Sighting." And with this sentence hanging in the air, she retires to her boudoir. The butler ushers the guest to Mauro Deserta; then puff! Gaspar disintegrates, understudied now by a despondent B. Poltergeist fink! grumps V, eviscerating Bolivar and taking over. All semblance of their Dream Concordat now suspended, the lovers epiphanize, square up for a sonar showdown-circa, Italian western. Squinty, balletic, transcendental. Putting down each other's bevatrons, cyclotrons and chronotrons. 
10

A blue beacon settles on the gray tundra. Somewhere, a reverberative whiningthe baying of wolves; also Milrow tsunamis, enveloping fog. A stir, a rustle: there they are, the Cobalt Children, or ambulant vegetables with ashen rags, stricken eyes, spiky arms stretched out before them. Back and forth they glide, like the weird incrustations of Picasso's Guernica. Invoking encyclical Popes, V intones: Libera me, Domine, de morte aeterna, in die illa tremend: Quando coeli movendi sunt et terra. Dum veneris judicate saeculum per igmen ...

V.

And you saw them ...

V.

... In their rags ...

V.

Eyes like ashes...

V.

... And they spoke to you ...

V.

... And you told them ...

V.

What it was like...

V.

... And the birds disappeared ...

B.

Extinction of the aves ...

B.

Van Allens ...

B.

No wings but propulsion.

B.

They told me about...

B.

Suddenly, luminous ...
B.

I saw them.

B.

In their petrified ashen rage.

B.

Bodies like coffins.

B.

I spoke to them.

B.

How it was ...

B.

Lightning and lithmus from the machine...

V.

What was left in the sky then?

V.

Angels with diesel infra-structure.

$\mathrm{V}$.

What else did you tell them?

V.

The abacus of Mazda.

V.

Was there much pain?

B.

and mothers ...

$\mathrm{V}$.

Tell me about the homes, the schools, the hospitals, the orphanages . . .

Like that!

B.

So fast?

V.

V.

And the fiords and lagoons?

V.

And the geological strata?

$\mathrm{V}$.

And then? 
B.

Silence, solitude.

B.

Summa-Apocalypse.

B.

Paradise restrained.

B.

Adam ate The Bomb

B.

So he could kill Abel.
V.

Like genesis.

V.

Edenic impedimenta.

V.

And the Tree of Knowledge?

V.

And Cain was born?

V.

And that was how it all began ...

\section{1}

STOP! protested B whose Cyclops Complex refracted Nth Declensions, Somalian sunsets and post-Cybernetics crematoria. $\mathrm{V}$ went ape: crisscrossing wires, plugging into taboo circuits and verboten valves, gassing up, getting overslick unto maudlin. KA-PUTT!!! yelped B. Their dream had quadrupled in zodiacal negations, zonkl the output zipped into generic sequestrations, delinearized from B's calibrations, and was gggrrgggrrrnnnggg! zapping out the master fuseboxPHFFFFT! Their Ghordian Clot was cut. And so, for milleniums, having bugged each other's dream and short-circuiting in this erotica; choked, charred and ultimately catatonic, their alter-genitalia lay strewn/strung from chrysalis to crucifixion-virginal and sainted upon the alter of miscegenation. Squatted on volcanic atolls with their segregated geniuses were Vergis IV and Bartolome V, all their ribaldries now ended. Sine die ...

ADDENDUM: This talismanic microfilm will self-destruct after a mega-cantabile, along with its time capsule. QUERY TO READER: Are you the LOGICAL placenta of $V \& B$ ? 